International Journal of Instruction

e-ISSN: 1308-1470 • www.e-iji.net
July $2019 \bullet$ Vol.12, No.3

p-ISSN: 1694-609X

pp. $35-50$

Received: 24/10/2018

Revision: 01/03/2019

Accepted: 08/03/2019

OnlineFirst:05/04/2019

\title{
The Effect of Genre-Based Mentoring on Rhetorical Quality of Research Article Drafts by Indonesian Lecturers in Social Sciences and Humanities
}

\author{
Arono \\ English Education Postgraduate Program of Bengkulu University, Indonesia, \\ arono@unib.ac.id
}

\section{Safnil Arsyad}

Prof. at English Education Postgraduate Program of Bengkulu University, Indonesia, safnil@unib.ac.id

Indonesian scholars in social sciences and humanities are far behind scholars in sciences and engineering in international journal publication and their unfamiliarity with English rhetorical style has been blamed as the main cause. The purpose of this study is to improve the rhetorical quality of research article drafts written by Indonesian university lecturers in social sciences and humanities. Using genrebased method, a group of 20 lecturers were mentored to improve the rhetorical quality of their research article abstracts, introductions, methods and discussions and their drafts were evaluated following the frameworks suggested by Swales (1990 and 2004), Swales et al., (2009), Peacock (2011) and Lim (2006). The results show that the rhetorical quality of the lecturer's article drafts satisfactorily improved in terms of the rhetorical moves and steps, the way they justify their research project and the number of references they use in their drafts. This implies that genre-based mentoring is effective enough to improve the ability of lecturers in writing research articles to be published in reputable international journals.

Keywords: genre-based mentoring, reputable international journals, research article, university lecturers, social sciences, humanities

\section{INTRODUCTION}

The number of Indonesian scholars who successfully published their research articles (RAs) in indexed or reputable international journals have improved significantly for the last few years. This is partly because Indonesian government always encourage and facilitate researchers to publish their research results in mainstream international journals. For example, regular seminars and workshops on journal article writing are conducted and financial incentives are awarded to those who successfully publish their research results in reputable international journals (Kemristekdikti, 2016). However,

Citation: Arono, \& Arsyad, S. (2019). The Effect of Genre-Based Mentoring on Rhetorical Quality of Research Article Drafts by Indonesian Lecturers in Social Sciences and Humanities. International Journal of Instruction, 12(3), 35-50. https://doi.org/10.29333/iji.2019.1233a 
according to Kemristekdikti, the majority of successful Indonesian scholars are from the fields of sciences and engineering, such as Computer Science, Agriculture and Biological Sciences, Physics and Astronomy, while scholars from social sciences and humanities including Applied Linguistics, Language Education and Linguistics are still unsuccessful. This implies among other things that, although writing articles in English is hard for all Indonesian scholars, it seems to be harder for scholars in social sciences and humanities than for those in other fields of discipline.

The success of Indonesian scholars from sciences and engineering in international journal publication is partly because they have a better access to international literature in English than those from social sciences and humanities. According to Adnan (2014), Indonesian scholars in sciences and engineering are generally better than those from social sciences and humanities in their intellectual capability, their education experiences and their access to academic books and journal articles published in English. This is because, as Adnan explains further, the majority of Indonesian scholars from sciences and engineering graduated from high quality universities in Indonesia or from a university in an English speaking country and therefore, their English ability is much better than their social sciences and humanities counterpart. Thus, since they have a better access to references in English, they seem to be more familiar with the writing style of English academic texts such as journal articles in English and be more successful in international journal publication.

Indonesian scholars in social sciences and humanities, on the other hand, have been found to be unfamiliar with the rhetorical style of English journal articles since they rarely refer to English articles published in international journals when writing academic texts. Studies have found that when writing articles in English, Indonesian scholars in social sciences and humanities tend to use the rhetorical style commonly found in Indonesian academic texts (Safnil, 2001, Mirahayuni, 2002, Adnan, 2009 and Arsyad and Arono, 2016). Thus, since they use Indonesian rhetorical styles when writing articles in English, their manuscripts still sound Indonesian and therefore are unlikely accepted by international journals. This is the main motivation for this study; that is to help Indonesian scholars in social sciences and humanities improve the rhetorical quality of their manuscript so that they can successfully publish their manuscripts in reputable international journals in English.

\section{REVIEW OF RELATED LITERATURE}

The introduction section of research articles (RAs) published in international journals in English is believed to have a common discourse structure based on the communicative purpose of each or group of sentences forming the section. Swales (1990 \& 2004) suggest that an ideal rhetorical framework for an RA introduction is create a research space or CARS consisting of moves and steps. Swales' CARS model of RA introduction is presented below.

Move 1: Establishing a territory

Step 1 Claiming centrality and/or

Step 2 Making topic generalization(s) and/or

Step 3 Reviewing items of previous research 
Move 2: Establishing a niche

Step 1A Counter claiming or

Step 1B Indicating a gap or

Step 1C Question-raising or

Step 1D Continuing a tradition

Move 3: Occupying a niche

Step 1A Outlining purposes or

Step 1B Announcing present research

Step 2 Announcing principle findings

Step 3 Indicating RA structure

This model has been examined in many subsequent studies on several different languages and cultures such as in Arabic by Najjar (1989), in Malay by Ahmad (1997) and in Indonesian by Safnil (2001) and Adnan (2009). The above studies found that, research article introductions (RAIs) in different languages and cultures (Arabic, Malay and Indonesian) also consist of rhetorical moves and steps as suggested in CARS but they may have different names and number of moves and steps.

Other sections of RAs have also been scrutinized by genre analysts such as, abstracts by Swales et al., (2009), Ren and Li (2011), Tseng (2011) and Zhang et al., (2012), method sections by Peacock (2011), Lim (2006) and Swales and Feak (1994), results and discussion sections by Swales (1990), Dudley-Evans (1994), Holmes (1997) and Parkinson (2012). These studies also used genre-based analysis method in their data analysis technique; that is looking at the frequent communicative units or rhetorical moves and steps in a particular RA section. Similar to RA introduction, from the findings of these studies an ideal model consisting of moves and steps has also been suggested for each of these sections. The suggested models of RA sections (i.e., abstract, methods and discussion) are given below.

Rhetorical model for RA abstracts (Swales et al., 2009)

Move 1: Background/introduction/situation

Move 2: The purpose of the research

Move 3: Methodology/materials/subject or the procedure how research is conducted

Move 4: Results/Findings

Move 5: Conclusions/Significance

Rhetorical model for methods section (Lim, 2006)

Move 1: Describing data collection procedure/s

Step1: Describing the sample which includes the location of the sample, the size of the sample/population, the characteristics of the sample and the sampling technique or criterion

Step 2: Recounting steps in data collection

Step 3: Justifying the data collection procedure/s which include highlighting the advantages of using sample and showing the representativeness of the sample

Move 2: Delineating procedurals for measuring variables

Step 1: Presenting an overview of the design 
Step 2: Explaining methods of measuring variables which include specifying items in questionnaire/databases, defining variables and describing methods of measuring variables.

Step 3: Justifying the method/s of measuring variables which include citing previous research method/s and highlighting acceptability of the method/s.

Move 3: Elucidating data analysis procedurals

Step 1: Relating data analysis procedurals

Step 2: Justifying data analysis procedurals

Step 3: Previewing results

Rhetorical model for discussion section (Swales, 1990)

Move 1: background information is statement about theoretical and technical information as already addressed earlier in the RA

Move 2: statement of results is the claim made by the writer as the direct answer to their research question

Move 3: un/expected outcome is statement or comment on whether or not the research results or finding are as they are expected

Move 4: reference to previous research is a rhetorical attempt of writer/s to link the present research finding/s to the available relevant knowledge or information for the purpose of comparison or to support the present findings

Move 5: explanation is the writer's rhetorical attempt to logically convince readers why such unexpected or extraordinary results or findings of the present study occur; International Journal of Linguistics

Move 6: Exemplification is only an illustration or samples to strengthen or support the explanation

Move 7: deduction and hypothesis is the writer's claim on the level of interpretation of the research findings to a larger scope of topic or area

Move 8: recommendation is writer's suggestion on the application or implementation of the research findings in practical ways and/or suggestion for further studies in the same or similar topic.

As for CARS model, these models have also been reexamined by subsequent studies and used a guideline in the teaching of academic writing especially in the teaching of research article writing.

In Indonesian context, several genre analysis studies on RAs written in Indonesian or English by Indonesian authors have also been conducted such as, by Safnil (2001), Mirahayuni (2002), Basthomi (2006), Adnan (2009 \& 20011), Arsyad (2013), Arsyad and Wardhana (2014), Arsyad and Arono (2016), Arsyad et al., (2018) and Arsyad and Adila (2018). These studies found that, when writing in Indonesian the Indonesian authors use Indonesian RA rhetorical style but when writing in English they adjust their rhetorical style to match the ones acceptable by English readers in order to be acceptable by international journals. However, it seems that the rhetorical style adjustment is more successfully done by scholars in sciences and engineering than by those in social sciences and humanities. 


\section{The Rationale for the Study}

The above rhetorical studies investigated how Indonesian authors structure their RAs especially abstract, introduction, method and discussion sections in already published articles in English journal. However, as finished language products these articles might have gone through reviewing and editing processes conducted by journal editors and/or reviewers and by the authors themselves. The rhetorical differences found in the English RAs by Indonesian authors are not the real ones and this does not show the real problems experienced by Indonesian authors when writing articles in English. This study, therefore, investigated the real rhetorical weaknesses found RA drafts written by Indonesian authors in social sciences and humanities in all sections of the articles (i.e. abstract, introduction, method and results and discussion) and attempted to help them improve the rhetorical quality of their RA drafts using genre-based mentoring method. To address this issue, the following research questions were used as the guideline.

a. How can genre-based mentoring method help improve the rhetorical quality of RA abstracts written by Indonesian university academics in Social Sciences and Humanities?

b. How can genre-based mentoring method help improve the rhetorical quality of RA introduction sections written by Indonesian university academics in Social Sciences and Humanities?

c. How can genre-based mentoring method help improve the rhetorical quality of RA methods section written by Indonesian university academics in Social Sciences and Humanities? and

d. How can genre-based mentoring method help improve the rhetorical quality of RA discussion written by Indonesian university academics in Social Sciences and Humanities?

\section{Genre-Based Mentoring Workshop}

One way of helping writers improve the rhetotical quality of their RA drafts is by involving them in a mentoring workshop using genre-based method. Following Feez (1998), Bhatia (2004), Bawarshi \& Reiff (2010) and Rose \& Martin (2012), Burgos (2017) suggests that there are three main stages of implementing genre-based method in the teaching of academic writing; these are deconstructing a model text, joint text construction between an instructor and participants and participants constructing their own texts individually. According to Burgos, in the deconstruction model text the participants are shown with examples the key sections and subsections or elements, the lexico-grammar patterns and the linguistic features of the text of the same genre. In the joint construction stage, the instructor and participants work together revising or rewriting a sample of research article draft using the knowledge and experience they obtain from the first stage. Finally, in the individual text construction, the participants construct or revise their own texts; in this case the participants edited or rewrote their own article drafts with the help from the instructor.

In addition, in the deconstruction stage it is the instructor who is more dominant and active; in join construction, instructor and participants play an equally active role in constructing or revising a model text while in independent text construction, it is the 
participants who are more active and dominant (Yang, 2016). According to Yang, the principal behind genre-based teaching cycle is that, '...while teachers build discourse field and register; it promotes students' learning and help them to develop specific knowledge field and ultimately help them build distinctive language patterns in certain genre' (p. 38). In other words, the writing teaching processes through genre-based method move from building the knowledge of participants on the criteria of a good text (showing a model of a good quality text) to working together in constructing a good quality text (sharing knowledge and experiences in writing a text) and working individually to write the participant's own text with the help from the instructors (implementing the knowledge and experience to construct a different text).

\section{METHOD}

Twenty lecturers or researchers from 4 different universities and 1 institute in Bengkulu city: Bengkulu University (BU), Muhammadiyah University of Bengkulu (BMU), Hazairin University (HU), Dehasen University (DU) and State Islamic Institute (SII) of Bengkulu in social sciences and humanities disciplines were invited on purpose to participate in this study. The criteria of choosing the research participants were that the lecturers had written an RA draft either in Indonesian of English which has not been published in any journal and agreed to participate in the research project. The distribution of the research participants from the universities and institute is presented in Table 1 below.

Table 1

Distribution of Research Participants

\begin{tabular}{lllll}
\hline No & Universities & Code & Number of Participants & Percentage \\
\hline 1. & Bengkulu University & BU & 12 & 60 \\
2. & Bengkulu Muhammadiyah & BMU & 3 & 15 \\
& University & & & \\
3. & Dehasen University & DU & 3 & 15 \\
4. & Hazairin University & HU & 1 & 5 \\
5. & State Islamic Institute & SII & 1 & 5 \\
Total & & & 20 & $100 \%$ \\
\hline
\end{tabular}

As indicated in Table 1, the number of research participants among different universities and institute is not equal because the number of lecturers who have written an RA draft in the different universities and institute was also not equal. In fact not all lecturers in social sciences in these institutions are active researchers and if they do conduct research they may not be interested in or capable of writing the results in the form of RAs.

After the first workshop, the participants were requested to submit their full RA drafts either in English or Indonesian. Then the drafts were analyzed by the research team based on their rhetorical moves and steps following the frameworks suggested by Swales (1990 and 2004), Swales et al., (2009), Lim (2006) and Peacock (2011) as mentioned above. The analysis results were shown to the lecturers in a second workshop to show what the strengths and weaknesses of their drafts are and how to make them rhetorical better. Then, they were assigned to revise and submit their second drafts to be 
analyzed by the research team and again the results were presented to them in the third workshop. Additional individual or group discussions were also held upon request from the participants. The mentoring workshops were conducted following the three stages of genre-based teaching method as discussed below.

\section{The Mentoring Workshop}

The RA drafts from the research participants were first examined using genre-based text analysis to see the rhetorical weaknesses in their RA drafts written in Indonesian or English. All sections (i.e., abstract, introduction, methods and discussion) of the RA drafts were analyzed following the frameworks suggested by previous researchers such as Swales (1990 and 2004), Swales et al., (2009), Peacock (2011) and Lim (2006) as presented above. The participants were introduced with examples to ideal rhetorical style of research article abstract, introductions, methods and discussion in a series of mentoring workshops and they were asked to revise each section of their RA drafts following the suggestions, corrections and recommendations from the mentors. The revised article drafts became their second and third drafts in this study. Similar to their first drafts, their second and third drafts were also analyzed in order to see the rhetorical quality improvement of their RA drafts and the results were then given and explained to them for further revision. Finally they were asked to revise their drafts for their third time and the rhetorical quality improvement of their article drafts from the first, second and third drafts are presented in tables.

\section{Data Analysis Technique}

The steps of analyzing the rhetorical moves and steps in all sections of the RA drafts were carried out in the following ways. First, we read the titles, the abstracts and the key words in each draft to get a thorough understanding of the research reported in the RAs drafts. Second, we read the entire draft to determine the main parts (i.e. abstract, introduction, methods, results and discussion and conclusion) of the article. Third, we read again every section of the RA drafts to classify the linguistic and discourse indications which may give a sign to the possible rhetorical moves and steps in each part referring to the above framework. Fourth, the possible rhetorical moves and steps were identifies and coded with the help of linguistic and discourse clues such as subheadings, paragraph as a unit of ideas, specific lexicons, discourse markers, and/or inferring from the text. Finally, since analyzing the rhetorical moves and steps in each section of RA drafts may involve subjective judgment of the researchers, four independent raters were asked to identify and coded the moves and steps in all RA drafts in order to ensure the reliability of text analysis results.

Four independent raters involved in this study were postgraduate students at the English Education Postgraduate Program of Education Faculty of Bengkulu University. First, the independent raters were trained on how to identify and code the possible moves and steps in the texts with examples following a particular rhetorical analysis procedure as commonly found in text analysis studies. Then, they were given two weeks to do the processes of move and step identification analysis of all 60 RA drafts from the corpus of this study. Inter-rater correlation agreement was then calculated and the results show an 
80 per cent agreement or an excellent inter-rater agreement (Orwin, 1994 as cited in Kanoksilapatham, 2005). The difference only occurred in identifying and coding the possible communicative units found in the RA introductions and discussion while almost no difference occurred in identifying and coding the other sections of the RA drafts. After a few discussions between the researcher and the co-raters, full agreement was finally achieved.

The frequency occurrence of necessary moves and steps in each section of the article drafts was calculated, compared and displayed in a table. By comparing the moves, the significant differences and improvement can be revealed by researchers. Thus, in order to see whether or not there is an improvement in the rhetorical quality of the RA drafts from draft 1 to draft 3 , the total number of RA drafts with necessary moves and steps in each draft was compared.

\section{FINDINGS}

\section{Rhetorical Quality Improvement of the RA Abstracts}

Genre-based text analyses were done on the three drafts (i.e., draft 1,2 and 3) prepared by the research participants after they received comments, corrections and advise from the mentors. The number of RA drafts with necessary moves and steps in the abstracts from draft 1 to draft 3 is displayed in the following table.

Table 2

The Distribution of Moves in the RA Abstracts

\begin{tabular}{cllll}
\hline Move & Description & Draft 1 & Draft 2 & Draft 3 \\
\hline Move-1 & Background/introduction/situation & 15 & 17 & 19 \\
Move-2 & The purpose of the research & 14 & 19 & 19 \\
Move-3 & $\begin{array}{l}\text { Methodology/materials/subject or the } \\
\text { procedure how research is conducted }\end{array}$ & 17 & 20 & 20 \\
Move-4 & Results/findings & 17 & 20 & 20 \\
Move-5 & Conclusion/significance & 9 & 18 & 19 \\
Total & & 72 & 94 & 97 \\
\hline
\end{tabular}

As shown in Table 2, the rhetorical quality improvement of the RA drafts from draft 1 to draft 3 can been by comparing the total freuqency of Moves in each draft (i.e., 72 in draft 1 to 97 in draft 3). In particular, the number of abstracts with a Move 1, has significantly increased from 15 abstracts in draft 1 to 19 abstracts in draft 3. Below are examples of Move-1 in draft 3 of RA abstracts.

\section{Extract 1:}

a. In dealing with educational issues in a country, a president needs a proper rhetorical structure is used in every state speech. In particular, president Joko Widodo has characteristics in using his rhetorical structure.(Move-1-BU-Noe)

b. Computer-Based National Exam (CBNE) is a modernization policy in the field of education based on information technology. The implementation of the CBNE is basically to improve the efficiency, quality, reliability, credibility, and integrity of the exam. (Move-1-DU-Evi) 
c. Universities have not been effective in developing students 'critical thinking skills, because lecturers do not understand how teaching techniques to develop critical thinking skills, consequently the students' critical thinking ability is still low. (Move-1-BMU-Irw)

As can be seen from extract 1 ( $a, b$ and $c)$, the writers do not directly state the purpose of their research at the beginning of their abstracts; they write a lead-in sentence first as a background to introduce readers to their research purposes as well as to attract them to read the entire abstract and article.

\section{Rhetorical Quality Improvement of RA Introductions}

As to abstracts, genre-based analyses were also conducted on the RA introductions written by the research participants of their first, second and third drafts and the results are shown in the following table.

Table 3

The Distribution of Moves and Steps in the RA Introductions

\begin{tabular}{cllll}
\hline Move & Description & Draft 1 & Draft 2 & Draft 3 \\
\hline Move-1 & Establishing a territory & 9 & 15 & 20 \\
\hline Step-A & Claiming centrality & 11 & 17 & 20 \\
\hline Step-B & Making topic generalization & & 15 & 20 \\
\hline Step-C & Reviewing items from previous research & 8 & & \\
\hline Move-2 & Establishing a niche & 4 & 4 & 4 \\
\hline Step-A & Counter claiming & 7 & 12 & 20 \\
\hline Step-B & Indicating a gap & - & - & - \\
\hline Step-C & Question-raising & - & - & - \\
\hline Step-D & Continuing a tradition & & & \\
\hline Move-3 & Occupying a niche & 2 & 10 & 20 \\
\hline Step-A & Outlining purposes & 11 & 11 & 11 \\
\hline Step-B & Announcing present research & 2 & 2 & 2 \\
\hline Step-C & Announcing principle findings & - & - & - \\
\hline Step-D & Indicating research article structure & & & \\
\hline
\end{tabular}

The two main questions to answer in an RA introduction are why the title is important and/or interesting and why the research is important or necessary. To answer these two questions, writers must use references to support their claims in order to be more argumentative and convincing. As Table 3 indicates, the lecturer's RA drafts improved significantly in terms of the use of important rhetorical moves and steps in their RA introductions such as, the use of Move-1-Step-A (claiming centrality), Move-1-Step-C (reviewing items from previous research), Move-2-Step-B (indicating a gap) and Move3-Step-A (outlining purposes). Below are examples of two most important elements (i.e., Move-1-Step-A and Move-2-Step-B) taken from the lecturers' RA drafts. Extract 2:

English textbook is one of the media as printed materials. It is common medium which is used by teachers to teach their students. Textbook is considered as the 
key component in most language programs and serves as the basis for language inputs ... (Move-1-Step-A-DH-YN)

The title of the above article is 'Evaluating of English Textbook of 2013 Curriculum Taught at Grade 12 of Vocational High School.' As can be seen in the above example, the writer starts her RA introduction by directly discussing 'English textbook' used in language programs as the title says.

Different from their first drafts, the writers have also reviewed relevant studies (Move-1Step-C) in their RA introduction in order to support the importance of their research project (Move-2-Step-B) as commonly found in RA introductions published in international journals. Below is an example.

Extract 3:

The above studies are important in order to know what the real problem that teachers face in the classroom. However, none of those studies above focus on the problem in delivering curriculum demand and only forcing by the curriculum... (Move-2-Step-B-BU-FDP)

In the above example, the writer reviewed three relevant studies on possible problems faced by teachers in English classes, such as poor student's motivation, limited teaching and learning facilities, insufficient time allocated for English subject in the curriculum, rare usage of English outside the classroom, teacher's insufficient competence in teaching English, and so on. Then, the writer concludes that there is no study yet focusing on the problems faced by English teachers in delivering a particular curriculum and this reason why her study was conducted.

\section{Rhetorical Quality Improvement of RA Methods}

The analyses results on the method section of the lecturers' RA drafts from draft 1, 2 and 3 are given in the following table.

Table 4

The Distribution of Moves in the RA Methods

\begin{tabular}{cllll}
\hline Moves & Description & Draft 1 & Draft 2 & Draft 3 \\
\hline Move 1 & Describing the data collection procedure/s & 20 & 20 & 20 \\
\hline Move 2 & Delineating procedurals for measuring variables & 17 & 17 & 19 \\
\hline Move 3 & Elucidating data analysis procedurals & 15 & 16 & 20 \\
\hline Total & & 52 & 53 & 59 \\
\hline
\end{tabular}

Table 4 shows that the most significant improvement of the writer's RA method section is on the use of Move-3 (elucidating data analysis procedurals). Through this rhetorical move, RA writers explain in detail the processes of their data analyses so that readers understand and believe that the research data are valid and reliable and therefore the research findings can be trusted. Below is an example of a Move-3 taken from the data.

\section{Extract 4:}

Correlations were implemented to scrutinize the relationship between WTC and attitude, classroom environment and confidence in English in communication whereas multiple regression analyses were applied to discern predictors for 
WTC. After getting the influential predictors, the deep-interviews were utilized to get more comprehensive data. I transcribed, read and reread the interview data before coding them and interpret them (Move-3-HU-Syl).

In the above example, the writer explains in quite detail how she analyzed the quantitative data of her research; that is by using multiple regression statistical analyses and transcribed, read, reread and interpreted the qualitative data.

\section{Rhetorical Quality Improvement of RA Discussions}

The distribution of rhetorical moves improvement in the discussion section of the lecturers' RA drafts from draft 1, 2 and 3 is displayed in the following table.

Table 5

The Distribution of Moves in the RA Discussion

\begin{tabular}{lllll}
\hline Moves & Description & Draft 1 & Draft 2 & Draft 3 \\
\hline Move-1 & Background information & 17 & 19 & 20 \\
\hline Move-2 & Statement of results & 15 & 20 & 20 \\
\hline Move-3 & Un/expected outcome & - & - & - \\
\hline Move-4 & Reference to previous research results/findings & 10 & 15 & 20 \\
\hline Move-5 & Explanation or interpretation of results & 16 & 20 & 20 \\
\hline Move-6 & Exemplification & 4 & 5 & 5 \\
\hline Move-7 & Deduction and hypothesis & 6 & 7 & 7 \\
\hline Move-8 & Recommendation & 2 & 4 & 4 \\
\hline Total & & 70 & 90 & 96 \\
\hline
\end{tabular}

Table 5 indicates that at least two rhetorical moves improved significantly in the lecturers' third drafts; these are Move-4 (Explanation or interpretation of results) and Move-5 (Explanation or interpretation of results). These two moves are important moves in the results and discussion section because through these rhetorical works authors explain and interpret their findings and convince readers that their new knowledge claims are interesting and important. Below are examples taken from the data of this study.

\section{Extract 5:}

a. Error in translating idioms has the highest percentage at $87.5 \%$ among three types of error in translation. It means that idioms are the most difficult part for the students to do translation. It happened because idioms cannot be understood from the literal meaning of the words which they are composed from; or they are difficult to understand from individual words (Redman, 1997). (Move-4-SII-ARN)

b. Similar finding has been reported by Ibrahim (2017) in his research that students had difficulties in translating Indonesian texts to English because of grammatical categories, linguistic level, lexical items, and some differences between source language with target language. (Move-5-SIIARN) 
Extract 5a shows that the authors interpreted their research results and the interpretation is supported with a reference. Second, in extract $5 \mathrm{~b}$, authors compared their research finding with the one by another researcher found in the literature. These two rhetorical works are very important and become compulsory moves in an RA discussion section as in Swales (1990)'s framework.

\section{DISCUSSION}

As presented with examples above, the quality of the lecturers' RA drafts (i.e., abstract, introduction, method and discussion sections) significantly improved in terms of the number of moves and steps used in each section of the RA drafts from drafts 1, 2 and 3 and the way the research participants use references to help strengthen their argument. For example, they have started their RA abstracts with an introduction or lead-in sentence following the model suggested by Swales et al., (2009). With this first sentence, it is expected that journal readers will be more attracted to read their abstracts and RAs as a whole. This is because, according to Zhang et al., (2012), the existence of introduction or Move-1 in an RA abstract helps strengthen the argument of the abstract and through this move, authors can persuasively attract readers to read the entire abstract and article.

The lecturers have also used references from the very beginning of their RA introductions to support the importance of their research topic. According to Swales (1990), the first sentence in an RA introduction will give a strong impression to the readers and therefore, it must be written argumentatively. One way of fascinating readers to read the article, as suggested by Swales, is to show that such topic has become a 'lively', 'significant' or 'well-established research area' (p:144). Other ways of affecting readers to the research topic, as Swales suggests further, are by referring to the typical, popular or the main nature of the topic or by suggesting that there are many other researchers working in the area. These various rhetorical works are aimed at appealing to readers so that they read the entire article and this can be effectively achieved using support from relevant references.

The lecturers have reviewed relevant studies in the literature and searched for knowledge gap in the studies in order to support the importance of their research. This shows that they have grounded their research project based on the evaluation results of previous relevant studies as suggested in the CARS model of Swales (1990 and 2004). According to Feak and Swales (2011), authors need to relate their research to those already reported by other authors in order to show readers that their research has some kind of additional information or new knowledge to the already claimed one in the literature. The lecturers' have also explained and interpreted their research results and supported them with relevant references and compared them with the findings of previous relevant studies in their discussion section using references following the ideal framework of RA discussion as suggested by Swales (1990).

The above evidences confirm what Carstens (2009) claims that although with criticisms, genre-based approach has proved to be successful in language teaching at school level at university level. According to Widodo (2006), a possible strength of genre-based 
approach in academic writing instruction is that the instructor focuses not only on the writing product which is here an RA but also on the writing processes in order that the participants can write rhetorically better. Thus, in genre-based mentoring approach the instructor and participants together analyzed the necessary components or Move and Steps in samples of published RAs before they analyzed and revised their own RA drafts in groups or individually.

The finding of this study is also in line with the one by Sadeghi et al., (2013) who found that genre-based method was effective in the teaching of reading and writing especially in English as a foreign language (EFL) and English for a specific purpose (ESP) classes. According to Sadeghi et al., the success of this method in EFL and ESP teaching is due to the 'learners' context', 'levels of proficiency', 'genre sensitivity', and 'many other social differences' (p:1015). In other words, the success of genre-based approach or method is determined by several factors such student's English proficiency, student's knowledge about the particular genre, the participants' schema on the content of the text to be read and/or written and so on. Thus, genre-based approach will be successful only if they meet the necessary factors and therefore, teachers must prepare the lecturers in the pre-teaching activities so that they can be well-prepared and potentially successful.

Similar finding was found by Elashri (2013) suggesting that genre-based approach helped new authors or postgraduate students improve not only their writing ability but also their positive writing attitude. According to Elashri, genre-based approach helped improve student's attitude toward writing because writing is taught as a process and this encourages lecturers to be good writers. In the learning processes, lecturers were actively involved in analyzing the communicative units of text models and producing such communicative units of their own and this happened in a non-threatening atmosphere because they do not emphasize the finished product of their writing to be marked.

\section{CONCLUSION}

All sections of the lecturers' RA drafts have satisfactorily improved from drafts 1, 2 and 3 in terms of the rhetorical moves and steps used in every section and the writing style adopted in their RA drafts. Their article drafts have also been more argumentative and convincing with the use of more relevant references in their articles. This implies that the explicit instruction of academic writing through genre-based mentoring has been successful enough in educating university lecturers in social sciences and humanities in preparing their RAs for international journal publication. It is believed that the lecturers' drafts are better in terms of their rhetorical style and have a better chance to be accepted for publication in a reputable international journal.

Further studies need to be done on how to educate Indonesian scholars in social sciences and humanities to be able to write better RAs in English not only from the view of rhetorical quality but also from the content quality. This can be better done by organizing mentoring workshops involving field specialists or successful authors in a particular field of discipline so that they can share their knowledge and experiences in 
writing RAs in English for international journal publication to scholars or researchers in the same field.

\section{ACKNOWLEDGEMENT}

This research was financially supported by the Ministry of Research, Technology and Higher Education of the Republic of Indonesia through Directorate of Research and Community Services (DRPM) on postgraduate team research schema of 2018. Therefore, we would like to express our sincere gratitude to them. All opinions, findings, and conclusions or recommendations expressed in this article are those of the authors and do not necessarily reflect the views of the respected party.

\section{REFERENCES}

Adnan, Z. (2009). Some potential problems for research articles written by Indonesian academics when submitted to international English language journals. The Asian EFL Journal Quarterly, 11(1), 107-125.

Adnan, Z. (2011). Ideal-problem-solution (IPS) model: A discourse model of research article introductions (RAIs) in education. Australian Review of Applied Linguistics, 34(1), 75-103.

Adnan, Z. (2014). Prospects of Indonesian research articles (RAs) being considered for publication in center journals: A comparative study of rhetorical patterns of RAs in selected humanities and hard science discipline. In A. Lyda \& K. Warchal (Eds.), Occupying niches: Interculturality, cross-culturality and aculturality in academic research (pp. 79-99). Heidelberg, NY: Springer. https://doi.org/10.1007/978-3-31902526-1

Ahmad, U. K. (1997). Scientific research articles in Malay: A situated discourse analysis (Unpublished doctoral dissertation). University of Michigan, Ann Arbor.

Arsyad, S. (2013). A genre-based analysis of Indonesian research articles in the social sciences and humanities written by Indonesian speakers. Journal of Multicultural Discourses, 8(3), 234-254.

Arsyad, S. (2014). Introduction in Indonesian social sciences and humanities research articles: How Indonesian writers justify their research project. Linguistik Indonesia, 32(2), 149-164.

Arsyad, S., \& Arono. (2016). Potential problematic rhetorical style transfer from first language to foreign language: A case of Indonesian authors writing research article introductions in English. Journal of Multicultural Discourses, 11(3), 315-350.

Arsyad, S., \& Adila, D. (2018). Using local style when writing in English: The citing behaviour of Indonesian authors in English research article introductions. Asian Englishes, 20(2), 170-185.

Arsyad, S., Zaim, M., \& Susyla, D. (2018). Review and citation style in research article introductions: A comparative study between national and international English medium journals in medical sciences. Discourse and Interaction, 11(1), 28-51. 
Basthomi, Y. (2006). Examining research spaces in doctoral prospectuses. TEFLIN Journal, 20(2), 140-158.

Bhatia, V. K. (2004). Worlds of written discourse: A genre-based view. London, England: Continuum.

Bawarshi, A., \& Reiff, M. J. (2010). Genre: An introduction to history, theory, research, and pedagogy. West Lafayette, IN: Parlor Press.

Burgos, E. G. (2017). Use of the genre-based approach to teach expository essays to English pedagogy students. HOW, 24(2), 141-159. Retrieved from http://dx.doi.org/10.19183/how.24.2.330

Carstens, A. (2009). The effectiveness of genre-based approaches in teaching academic writing: Subject-specific versus cross-disciplinary emphases (Unpublished doctoral dissertation). University of Pretoria, Pretoria, South Africa.

Dudley-Evans, T. (1994). Genre analysis: An approach to text analysis for ESP. In M. Coulthard (Ed.), Advances in written text analysis (pp. 219-228). London, England: Routledge.

Elashri, I. I. A. (2013). The effect of the genre-based approach to teaching writing on the EFL Al-Azhar secondary students' writing skill and their attitude toward writing (Unpublished doctoral thesis). Mansoura University, Mansoura, Egypt.

Feak, C. B., \& Swales, J. M. (2011). Creating contexts: Writing introductions across genres. Ann Arbor, MI: The Michigan University Press.

Feez, S. (1998). Text-based syllabus design. Sydney, Australia: National Centre for English Language Teaching and Research.

Holmes, R. (1997). Genre analysis, and the social sciences: An investigation of the structure of RA discussion sections in three disciplines. English for Specific Purposes, 16(4), 321-337.

Holmes, R. (1999). Academic attribution: Citation and the construction of disciplinary knowledge. Applied Linguistics, 20, 341-367.

Kanoksilapatham, B. (2005). Rhetorical structure of biochemistry research articles. English for Specific Purposes, 24(3), 269-292.

Kemristekdikti (2016). Kekuatan 50 institusi ilmiah Indonesia: Profil publikasi ilmiah terindeks Scopus [The strength of 50 Indonesian universities: Publication profile in Scopus indexed journals]. Jakarta, Indonesia: Direktorat Pengelolaan Kekayaan Intelektual, Direktorat Jenderal Penguatan Riset dan Pengembangan Kemristekdikti Indonesia.

Lim, J. M. (2006). Method sections of management research articles: A pedagogically motivated qualitative study. English for Specific Purposes, 25(3), 282-309.

Mirahayuni, N. K. (2002). Investigating textual structure in native and non-native English research articles: Strategy differences between English and Indonesian writers (Unpublished doctoral thesis). The University of New South Wales, Sydney, Australia. 
Najjar, H. Y. (1989). Scientific Arabic: The agricultural research article (Unpublished doctoral thesis). University of Michigan, Ann Arbor.

Parkinson, J. (2011). The discussion section as argument: The language used to prove knowledge claims. English for Specific Purposes, 30(3), 164-175.

Peacock, M. (2011). The structure of the method section in research articles across eight disciplines. The Asian ESP Journal, 7(2), 99-123.

Ren, H. \& Li, Y. (2011). A comparative study on the rhetorical moves of abstracts in published research articles and master's foreign language theses. English Language Teaching, 4(1), 162-166. Retrieved from http://www.ccsenet.org/ journal/index.php/elt/article/view/9678

Rose, D., \& Martin, J. R. (2012). Learning to write, reading to learn: Genre, knowledge and pedagogy in the Sydney school. Sheffield, England: Equinox.

Swales, J. M. (1990). Genre Analysis: English in Academic and Research Settings, Cambridge, England: Cambridge University Press.

Swales, J. M. (2004). Research genres: Explorations and applications. Cambridge, England: Cambridge University Press.

Swales, J. M., \& Feak, C. B. (1994). Academic writing for graduate students: Essential tasks and skills: A course for non-native speakers of English. Ann Arbor, MI: The University of Michigan Press.

Swales, J.M, Irwin, V., \& Feak, C.B. (2009). Online commentary for abstracts and the writing of abstracts. Ann Arbor, MI: The University of Michigan Press.

Sadeghi, B., Hassani, M. T., \& Hemmati, M. R. (2013). The effect of genre-based instruction on ESP learners reading comprehension in theory and practice. Language Studies, 3(6), 1009-1020.

Safnil. (2001). Genre structure analyses of the Indonesian research articles (Unpublished doctoral thesis). The Australian National University, Canberra, Australia.

Tseng, F. (2011). Analyses of moves structure and verb tense of research article abstracts in applied linguistics journals. International Journal of English Linguistics, 1 (2), 27-39. Retrieved from http://www.ccsenct.org/ journal/index.php/ijel/article/viewFile

Widodo, H. P. (2006). Designing a genre-based lesson plan for an academic writing course. English Teaching Practice and Critique, 5(3), 173-199.

Yang, Y. (2016). Teaching Chinese college ESL writing: A genre-based approach. English Language Teaching, 9(9), 36-44.

Zhang, B., Quyen, B. T. T., \& Pramoolsook, I. (2012). Moves and linguistic realizations: English research article abstracts by Vietnamese agricultural researchers. The Asian ESP Journal, 8(3), 126- 149. Retrieved from http://asian-espjournal.com/Volume 8-3 Pdf. October 2012 